\title{
RANCANGAN PENYULUHAN UNTUK MENGUBAH PERSEPSI PETANI UBI JALAR TERHADAP PENGENDALIAN HAMA LANAS MENGGUNAKAN DAUN MIMBA DAN FEROMON
}

\author{
Design Extention for Change Farmers Perceptions of Sweet Potato Weevil \\ (Control through the Use of Pheromones and Neem Leaf Vegetable Insecticides)
}

\author{
Desandi A.M. Ramadhiana ${ }^{1 *}$, Rudi Hartono ${ }^{1}$, Nazaruddin ${ }^{2}$ \\ ${ }^{1}$ Program Studi Penyuluhan Pertanian Berkelanjutan \\ ${ }^{2}$ Program Studi Agribisnis Hortikultura \\ Jurusan Pertanian Politeknik Pembangunan Pertanian Bogor \\ *Email: dsandiamr@gmail.com
}

\begin{abstract}
One of the obstacles in the sweet potato production system is the attack of the sweet potato weevil (Cylas Formicarius) that is the main pest on sweet potato plants. The efforts of farmers in Maja District to deal with these pests are still low and depend on the use of chemical pesticides. The behaviour of farmers is influenced by the perception of farmers who consider chemical pesticides to be the main solution in controlling plant-disturbing organisms. Innovations in pest control can be carried out with preventive measures such as the use of pheromone that trap and disrupt pest mating and plant-based insecticides that are more environmentally friendly. The study aims to analyze the perception of sweet potato farmers on controlling sweet potato weevil pests through the use of pheromones and neem leaf vegetable insecticides, related factors and strategies that can be done in increasing farmers' perceptions. The results of descriptive analysis of 72 sample respondents can be seen that the perception of sweet potato farmers in Maja District on the use of pheromones and neem leaf vegetable insecticides in controlling sweet potato weevil pests is in the poor category with a value of $49.9 \%$. The results of the correlation analysis of rank spearman at a significance level of $5 \%(0.05)$ show related factors including land area, income, technical aspects and social interaction.
\end{abstract}

Keywords: perception, pheromones, sweet potato weevil, vegetable insecticides

\begin{abstract}
ABSTRAK
Salah satu kendala dalam sistem produksi ubi jalar adalah serangan hama lanas (Cylas formicarius) yang merupakan hama utama pada tanaman ubi jalar. Upaya yang dilakukan petani di Kecamatan Maja dalam menanggulangi hama tersebut masih rendah dan bergantung pada penggunaan pestisida kimia. Kemungkinan Perilaku tersebut dipengaruhi oleh persepsi petani yang menganggap pestisida kimia merupakan solusi utama dalam mengendalikan organisme pengganggu tanaman. Inovasi dalam pengendalian hama lanas dapat dilakukan dengan tindakan preventif seperti penggunaan perangkap feromon yang berfungsi mengurangi perkawinan hama serta insektisida nabati yang lebih ramah lingkungan. Kajian ini bertujuan untuk menganalisis persepsi petani ubi jalar terhadap pengendalian hama lanas melalui penggunaan feromon serta insektisida nabati daun mimba, faktor-faktor yang berhubungan serta strategi yang dapat dilakukan dalam meningkatkan persepsi petani. Metodep peneliitian dilaksanakan secara purposive yaitu dengan cara sengaja. Hasil analisis deskriptif terhadap 72 responden sampel dapat diketahui bahwa persepsi petani ubi jalar di Kecamatan Maja terhadap penggunaan feromon serta insektisida nabati daun mimba dalam pengendalian hama lanas tergolong dalam kategori kurang baik dengan nilai $49,9 \%$. Hasil analisis korelasi rank spearman pada taraf signifikansi $5 \%(0,05)$ menunjukkan faktorfaktor yang berhubungan diantaranya luas lahan, pendapatan, aspek teknis dan interaksi sosial.
\end{abstract}

Kata Kunci: persepsi, feromon, kumbang ubi jalar, insektisida nabati 


\section{PENDAHULUAN}

Tanaman ubi jalar merupakan salah satu sumber tanaman pangan alternatif yang dapat memperkuat ketahanan pangan masyarakat, baik untuk konsumsi secara langsung maupun sebagai bahan pengolahan. Berdasarkan data BPS (2020), produksi ubi jalar di Kecamatan Maja menduduki peringkat kedua penyumbang hasil produksi terbesar di Kabupaten Majalengka dengan produktivitas sebesar 27,4 ton/ha. Namun produktivitas hasil tersebut mengalami penurunan dalam 2 tahun terakhir, dari tahun 2018 yang memiliki produktivitas sebanyak 29,5 ton/ha dan pada tahun 2019 sebesar 28,6 ton/ha.

Salah satu yang menjadi kendala utama dalam sistem produksi ubi jalar adalah adanya serangan hama lanas (Cylas formicarius) yang merupakan hama utama pada tanaman ubi jalar bahkan dapat menurunkan hasil produksi sebanyak 10- 80\% (Supriyatin, 2008). Berdasarkan programa BPP Kecamatan Maja tahun 2021, tingkat penerapan teknologi pengendalian hama pada tanaman ubi jalar masih sebesar $46 \%$, selain itu petani ubi jalar di Kecamatan Maja dalam upaya menanggulangi serangan hama masih tergantung pada penggunaan pestisida kimia sintetik. Perilaku tersebut dipengaruhi oleh persepsi petani menganggap pestisida kimia merupakan solusi tunggal dalam mengendalikan hama lanas dan organisme pengganggu tanaman lainnya.

Capinera (2014), menuturkan bahwa penggunaan insektisida kimia dalam pengendalian hama lanas pada tanaman ubi jalar dinilai kurang efektif dikarenakan larva lanas menyerang di dalam umbi sehingga aplikasinya tidak tepat sasaran selain itu pestisida kimia yang diaplikasikan secara intensif justru dapat meningkatkan resistensi hama dan residu yang berbahaya bagi lingkungan serta kesehatan manusia. Oleh karena itu, perlunya substitusi dalam mengatasi hama lanas pada tanaman ubi jalar.

Dalam konsep pengendalian hama dengan cara preventif memiliki banyak strategi salah satunya dengan penggunaan perangkap feromon yang berfungsi untuk mengacaukan perkawinan hama serangga jantan dan betina dengan penangkapan serangga jantan melalui feromon sehingga kumbang betina tidak ada yang mengawini dan tidak menghasilkan telur yang mengakibatkan larvanya tidak merusak umbi ubi jalar (Pasaribu, 2018). Adapun pestisida nabati merupakan pestisida dengan bahan yang berasal dari tumbuhan dan lebih ramah lingkungan. Menurut hasil penelitian Lapinangga dan Lopez (2018) diketahui bahwa efektivitas pestisida nabati tertinggi terhadap mortalitas hama lanas diperoleh dari daun mimba sebesar 97.5\%. Berdasarkan uraian tersebut maka penulis melaksanakan penelitian mengenai "Persepsi Petani Ubi Jalar terhadap Pengendalian Hama Lanas (Cylas formicarius) melalui Penggunaan Feromon serta Insektisida Nabati Daun Mimba di Kecamatan Maja".

\section{METODE PENELITIAN}

Kegiatan penelitian ini dilaksanakan selama tiga bulan mulai April. Kegiatan penelitian ini dilaksanakan selama tiga bulan, terhitung dari April sampai dengan Juni 2021 yang dilaksanakan pada 3 desa di Kecamatan Maja, yakni: Desa Banjaran, Desa Kertabasuki dan Desa Maja Selatan. Pemilihan lokasi pengkajian dilakukan secara purposive yaitu dengan cara sengaja. Pertimbangan bahwa daerah tersebut merupakan wilayah potensial dalam produksi ubi jalar.

Populasi dalam penelitian ini adalah seluruh petani yang 
melaksanakan usaha tani ubi jalar dan tergabung dalam kelompok tani yang berada di Desa Banjaran, Desa Maja Selatan dan Desa Kertabasuki Kecamatan Maja dengan jumlah anggota petani 221 orang. Sedangkan hasil perhitungan sampel dengan rumus Taro Yamane diperoleh jumlah sampel sebanyak 72 orang.

Uji validitas dilakukan dengan membagikan kuesioner kepada 15 orang responden dengan mengujikan instrumen atau kuesioner dengan format dan isi yang sama kepada petani lain dengan karakteristik yang sama dengan petani yang menjadi responden. Data hasil jawaban responden tersebut diolah menggunakan software Microsoft Excel dan SPSS Versi 26 untuk mencari nilai koefisien menggunakan rumus pearson product moment. Dari hasil uji validitas dengan t tabel bernilai 0,553 dinyatakan bahwa 50 butir instrumen penelitian dinyatakan valid. Uji reliabilitas instrumen dilakukan kepada 15 responden (sama pada pelaksanaan uji validitas). Data hasil jawaban responden tersebut diolah menggunakan software Microsoft Exceldan SPSS Versi 26. Hasil uji reliabilitas dengan menggunakan formula koefisien Alpha Cronbach sebesar 0,97 yang berarti sangat kuat.

Data yang digunakan dalam pengkajian ini adalah data primer dan data sekunder, data primer hendak diperoleh secara langsung dari petani ubi jalar yang menjadi responden. Pelaksanaan kajian ini dilakukan dengan cara sebagai berikut: 1) wawancara terstruktur; 2) angket (kuesioner) 3) observasi; dan 4) data sekunder sebagai data pendukung dari programa Balai Penyuluhan Pertanian Kecamatan Maja, Kecamatan Maja dalam angka tahun 2021 bukti, dokumentasi dan lain - lain secara terpantau.
Teknik analisis data yang digunakan yaitu analisis statistik deskriptif untuk menjawab tujuan nomor 1 (satu) dan 4 (empat) serta analisis korelasi Rank Spearman untuk menjawab tujuan nomor 2 (dua) dan 3 (tiga). Analisis deskriptif dilakukan dengan menentukan nilai ratarata hitung, persentasi atau proporsi data dan pengelompokan data. Analisis Rank Spearman menggunakan SPSS Versi 26 digunakan untuk menganalisis faktorfaktor yang berhubungan dengan persepsi petani.

Apabila nilai signifikansi (2-tailed) $\leq 0,05$ maka ada hubungan antar variabel yang signifikan dan sebaliknya. Penentuan tingkat kekuatan hubungan antar variabel dapat berpedoman pada nilai koefisien korelasi Sugiyono (2019) $0,00-0,25$ (sangat Lemah); 0,26 - 0,50 (cukup); 0,51 - 0,75 (kuat); 0,76-0,99 (sangat kuat); dan 1,00 (sempurna).

Apabila koefisien korelasi bernilai positif, maka hubungan kedua variabel dikatakan searah. Sebaliknya jika koefisien korelasi bernilai negatif, maka hubungan kedua variabel dikatakan tidak searah. Dari hasil kuesioner tersebut maka parameter dengan nilai terendah perlu dilakukannya perubahan atau peningkatan nilai terendah. $\mathrm{Hal}$ ini dijadikan dasar penyusunan materi utama dalam perancangan strategi yang berkaitan dengan kegiatan penyuluhan. Tujuan keempat dalam kajian ini yakni untuk mengkaji penggunaan feromon dengan dilakukan pada lahan petak percontohan. Hasil tersebut dianalisis secara deskriptif dengan menentukan nilai rata-rata hitung, tahapan hasil dari persentase atau proporsi data dan pengelompokan data melalui pengamatan jumlah hama yang terperangkap dalam daerah tersebut. Tahapan ini bertujuan untuk mengetahui tingkat kinerja feromon dalam mengatasi dan mengendalikan permasalahan terkait serangan hama pada budidaya pertanian. 


\section{HASIL DAN PEMBAHASAN}

\section{Persepsi Petani}

Analisis persepsi petani terhadap penggunaan feromon-lanas dan insektisida nabati daun mimba. Dari segi karakteristik inovasi sesuai dengan pernyataan dari A.W. van den Ban dan H.S. Hawkins (1999) bahwasanya persepsi penerima terhadap suatu inovasi ditinjau dari karakteristik inovasi teknologi tersebut. Karakteristik inovasi yang dapat mendukung persepsi petani meliputi keunggulan relatif, tingkat kesesuaian, tingkat kerumitan, kemudahan untuk dicoba dan kemudahan untuk diamati (Rogers, 2005). Hasil analisis deskriptif terkait skor persepsi petani serta kategorinya di setiap indikator penelitian ditunjukkan pada Tabel 1.

Tabel 1 Analisis Skor Persepsi Per Indikator

\begin{tabular}{|c|c|c|c|c|c|}
\hline No. & Indikator & $\begin{array}{l}\text { Skor yang } \\
\text { Diperoleh }\end{array}$ & $\begin{array}{c}\text { Skor } \\
\text { Maksimum }\end{array}$ & Persentase & Kategori \\
\hline 1. & $\begin{array}{l}\text { Keunggulan } \\
\text { relatif }\end{array}$ & 717 & 1152 & 62,24 & Cukup \\
\hline 2. & $\begin{array}{l}\text { Tingkat } \\
\text { kesesuaian }\end{array}$ & 627 & 1152 & 54,43 & Cukup \\
\hline 3. & $\begin{array}{l}\text { Tingkat } \\
\text { kerumitan }\end{array}$ & 693 & 1728 & 40,10 & Kurang \\
\hline 4. & $\begin{array}{l}\text { Kemudahan } \\
\text { dicoba }\end{array}$ & 218 & 576 & 37,84 & Kurang \\
\hline 5. & $\begin{array}{l}\text { Kemudahan } \\
\text { dilihat }\end{array}$ & 621 & 1152 & 53,90 & Cukup \\
\hline & Jumlah & 2876 & 5720 & 49,9 & Kurang \\
\hline
\end{tabular}

Sumber : Data primer yang diolah (2021)

Tabel 2 Analisis Skor Persepsi Per Responden

\begin{tabular}{cclcc}
\hline No. & $\begin{array}{l}\text { Interval } \\
\text { Skor }\end{array}$ & Kategori & Jumlah (orang) & Persentase (\%) \\
\hline 1. & $20-35$ & Tidak Baik & 26 & 36,1 \\
2. & $>35-50$ & Kurang Baik & 36 & 50,0 \\
3. & $>50-65$ & Cukup Baik & 10 & 13,9 \\
4. & $>65-80$ & Sangat Baik & - & - \\
\hline & Jumlah & & 72 & 100 \\
\hline
\end{tabular}

Sumber : Data primer yang diolah (2021)

Berdasarkan hasil analisis pada Tabel 1 dan 2 dapat diketahui bahwa secara keseluruhan persepsi petani ubi jalar di Kecamatan Maja terhadap penggunaan feromon serta insektisida nabati daun mimba dalam pengendalian hama lanas (Cylas formicarius) tergolong dalam kategori kurang baik dengan nilai $49,9 \%$. Hasil dari observasi dan wawancara bahwasanya petani ubi jalar di Kecamatan Maja masih merasa asing terhadap penggunaan perangkap feromon untuk mengendalikan hama lanas dikarenakan minimnya informasi yang didapatkan serta ketersediaannya yang masih jarang terdapat di kios tani terdekat. Petani ubi jalar di Kecamatan Maja terbiasa untuk tidak melakukan pengendalian hama dan hanya mengandalkan pada pengaturan drainase lahan, bahkan terkadang apabila ditemukan gejala serangan hama lanas 
dan lainnya pada ubi jalar, petani lebih memilih untuk melakukan penyemprotan dengan menggunakan pestisida kimia dibandingkan insektisida nabati dengan berbahan dasar daun mimba ataupun bahan organik lainnya yang terdapat di lingkungan sekitar dikarenakan para petani lebih memilih sesuatu yang lebih praktis dan tersedia di kios-kios tani dibandingkan pembuatan sendiri.

\section{Faktor-Faktor yang Berhubungan dengan Persepsi Petani}

\section{Karakteristik Responden}

Hasil data instrumen yang diperoleh melalui pengisian kuesioner dan wawancara terhadap 72 responden.

\section{Umur}

Hasil sebaran kuesioner kepada petani ubi jalar didapatkan mayoritas berada pada kategori petani tua yakni berumur 51 hingga 65 tahun sebanyak 35 orang dengan persentase $48,6 \%$, selanjutnya petani berumur 36 hingga 50 tahun sebanyak 21 orang atau $29,2 \%$, petani lanjut usia yang berumur lebih dari 65 tahun sebanyak 11 orang atau 15,3\% serta petani muda yang umurnya kurang dari 35 tahun sebanyak 5 orang atau $6,9 \%$. Angka usia produktif menurut BPS (2020) berada pada rentang umur 15 hingga 64 tahun, sehingga mayoritas responden berada pada umur produktif dalam pekerjaan usahatani. Setara dengan pernyataan Rahmawati (2016) yang menuturkan bahwa dalam umur produktif seseorang mempunyai kemampuan fisik yang optimal sehingga memiliki respon yang baik dalam menerima hal-hal baru dalam perbaikan usahataninya.

\section{Tingkat Pendidikan}

Berdasarkan hasil sebaran kuesioner didapatkan mayoritas tingkat pendidikan petani ubi jalar di Kecamatan
Maja yang menjadi responden berada pada kategori rendah atau lulus SD dengan persentase $54,2 \%$ dengan jumlah sebanyak 39 orang, di posisi selanjutnya yakni kategori sedang dengan lulus SMP sebesar $23,6 \%$ atau 17 orang serta lulus SMA sebesar $22,2 \%$ sebanyak 16 orang sedangkan untuk kategori sangat rendah atau yang tidak lulus SD tidak terdapat pada responden dalam pengkajian ini. Mayoritas pendidikan petani yang masih terbilang rendah ini dikarenakan pada masanya belum masuk era reformasi yang mewajibkan pendidikan selama 12 tahun sehingga responden lebih memilih untuk bekerja sebagai petani dibandingkan melanjutkan pendidikan.

Oleh karena itu perlu adanya upaya perhatian untuk regenerasi petani selanjutnya sesuai dengan pernyataan Kusnadi et al. (2011) menyatakan bahwa petani dengan pendidikan tinggi akan lebih terbuka dalam menerima informasi serta menerima perubahan teknologi mengenai pengelolaan usaha tani.

\section{Luas Lahan}

Berdasarkan hasil sebaran kuesioner kepada petani ubi jalar di Kecamatan Maja yang menjadi responden didapatkan mayoritas kategori luas lahan berada pada status petani kecil sebesar $36,1 \%$ dengan jumlah 26 orang, selanjutnya terdapat persamaan jumlah pada petani gurem dan petani besar sebanyak 23 orang dengan persentase nilai $31,9 \%$ sedangkan untuk kategori buruh tani tidak ada. Luas lahan memiliki dampak dalam upaya transfer dan penerapan teknologi.

\section{Pendapatan}

Berdasarkan hasil sebaran kuesioner didapatkan mayoritas tingkat pendapatan petani ubi jalar di Kecamatan Maja yang menjadi responden berada pada kategori rendah dengan persentase 
$43,1 \%$ dengan jumlah sebanyak 31 orang, pendapatan sedang sebanyak 17 orang dengan persentase $23,6 \%$, pendapatan kurang sebanyak 14 orang dengan persentase $19,4 \%$ dan terakhir responden yang memiliki pendapatan tinggi sejumlah 10 orang dengan persentase 13,9\%. Jumlah pendapatan yang bervariatif ini bergantung kepada luas lahan garapan serta kondisi dan kebutuhan agribisnis masing-masing petani yang beragam.

\section{Aspek Teknis}

Keuntungan relatif sesuatu hal berkaitan dengan teknologi pertanian dapat dinilai dari persepsi petani responden pada keuntungan segi teknis.

\section{Akses Informasi \\ Berdasarkan hasil penelitian menunjukkan bahwa 54,2\% akses informasi yang dilakukan petani ubi jalar di Kecamatan Maja berada pada kategori cukup dengan frekuensi 39 orang responden. Sedangkan 43,1\% lainnya berada pada kategori rendah dan 2,8\% berada pada kategori tinggi. Indikator akses terhadap informasi ditinjau berdasarkan frekuensi petani ubi jalar dalam mencari informasi yang berkaitan dengan pengendalian hama lanas dari lembaga pertanian seperti Balai Penyuluhan Pertanian (BPP) dan Dinas Pertanian daerah setempat ataupun melalui media tercetak seperti buku, majalah, koran dan media elektronik dari smartphone, televisi, radio begitu pula dari praktisi pertanian atau sesama petani lainnya.}

\section{Ketersediaan Bahan Pestisida}

diukur melalui keberadaan dan keterjangkauan dari bahan utama pestisida yakni feromon lanas dan pohon atau daun mimba. Hasil penelitian menunjukkan bahwa ketersediaan bahan pestisida mayoritas berada pada kategori rendah dengan persentase $84,7 \%$ sedangkan $15,3 \%$ lainnya berada pada kategori kurang. Artinya secara umum petani ubi jalar di Kecamatan Maja menilai bahwasanya ketersediaan dari feromon dan pohon mimba masih dirasa kurang. Hal ini dianggap wajar dikarenakan keberadaan dari feromon lanas untuk sekarang hanya mampu dibeli secara online serta untuk pohon mimba sebagai bahan insektisida keberadaan lokasinya jauh dari lahan petani bahkan sebagian petani tidak mengetahui bentuk dan karakteristik pohon mimba itu sendiri.

\section{Ketersediaan Sarana Penunjang}

Ketersediaan sarana penunjang dilihat dari ketersediaan sarana dan prasarana yang mampu menunjang dalam pembuatan perangkap feromon lanas dan pembuatan insektisda nabati daun mimba. Dari hasil analisis menunjukkan bahwa ketersediaan sarana penunjang sebanyak $43,1 \%$ berada pada kategori rendah, selanjutnya kategori kurang memiliki persentase $36,1 \%$ dengan jumlah 26 orang responden dan $15 \%$ sisanya berada pada kategori tinggi dengan jumlah 15 orang responden.

\section{Intensitas Penggunaan Pestisida Kimia}

Indikator intensitas penggunaan pestisida kimia diukur melalui frekuensi dan pengalaman petani ubi jalar di Kecamatan Maja dalam menggunakan bahan-bahan berdasar kimia. Hasil analisis menunjukkan bahwa 59,7\% berada pada kategori cukup dan 4,2\% berada pada kategori tinggi, sedangkan untuk $36,1 \%$ atau 26 petani responden lainnya sudah mengurangi penggunaan bahan sintetis.

\section{Kapasitas dalam PHT}

Indikator kapasitas dalam PHT dinilai melalui pengalaman dan kemampuan petani dalam melaksanakan 
berbagai metode dalam PHT (Pengendalian Hama Terpadu) pada budidaya ubi jalar. Hasil penelitian menunjukkan bahwa kapasitas petani ubi jalar dalam pengendalian hama di Kecamatan Maja terbilang masih rendah dengan persentase $84,7 \%$ berada pada kategori rendah dan $15,3 \%$ berada pada kategori kurang.

\section{Interaksi Sosial}

Indikator dari variabel interaksi sosial diukur melalui peran kelompok tani, peran penyuluh pertanian dan peran dari pengendali organisme pengganggu tanaman (POPT).

\section{Peran Kelompok tani}

Hasil analisis menunjukkan peran kelompok tani di Kecamatan Maja tergolong rendah dengan persentase $94,4 \%$ dan $5,6 \%$ berada pada kategori kurang. Indikator peran kelompok tani yaitu frekuensi dan keaktifan petani pada pertemuan dan melaksanakan fungsi dari kelompok tani sebagai sarana belajar, kerjasama dan sarana produksi budidaya ubi jalar dan pengendalian lanas.

\section{Peran Penyuluh Pertanian}

Indikator peran penyuluh pertanian ditinjau melalui kuantitas dan kualitas pertemuan yang dilakukan dengan penyuluh pertanian meliputi frekuensi pelaksanaan penyuluhan, penggunaan media dan metode yang dilakukan oleh penyuluh pertanian di wilayah binaannya dan konsultasi permasalahan yang dihadapi petani. Pada tabel menunjukkan bahwa peran penyuluh pertanian 58,3\% menganggap masih kurang dengan jumlah 42 orang responden dan 25 orang menganggap rendah dengan persentase $34,7 \%$ sedangkan $6,9 \%$ atau 5 orang lainnya menganggap cukup.

\section{Peran POPT}

Indikator peran POPT ditinjau melalui tugas dari POPT itu sendiri yakni melakukan pengamatan, peramalan, memberi rekomendasi dan melakukan bimbingan pada petani dalam pengendalian hama. Dari hasil analisis pada tabel di atas menunjukkan bahwa peran POPT di Kecamatan Maja 50\% kurang dan $48,6 \%$ rendah sedangkan $1,4 \%$ kategori cukup. Analisis hubungan variabel korelasi pada Tabel 3.

\section{ANALISIS HUBUNGAN VARIABEL}

Tabel 3 Hasil Analisis Korelasi Rank Spearman

\begin{tabular}{clccl}
\hline No. & \multicolumn{1}{c}{ Indikator } & $\begin{array}{c}\text { Taraf } \\
\text { Signifikansi }\end{array}$ & Koefisien & Keterangan \\
\hline 1 & Umur & 0,951 & 0,007 & Tidak Berhubungan \\
2 & Pendidikan & 0,608 & 0,061 & Tidak Berhubungan \\
3 & Luas lahan & $0,024^{*}$ & 0,266 & Berhubungan \\
4 & Pendapatan & $0,044^{*}$ & 0,238 & Berhubungan \\
5 & Akses Informasi & $0,002^{* *}$ & 0,362 & Berhubungan \\
6 & Ketersediaan bahan pestisida & $0,000^{* *}$ & 0,491 & Berhubungan \\
7 & Ketersediaan Sarana & $0,000^{* *}$ & 0,441 & Berhubungan \\
8 & Efektifitas bahan kimia & $0,000^{* *}$ & 0,514 & Berhubungan \\
9 & Kapasitas dalam pengendalian Hama & $0,002^{* *}$ & 0,366 & Berhubungan \\
10 & Peran Kelompok tani & $0,001^{* *}$ & 0,381 & Berhubungan \\
11 & Peran Penyuluh & $0,000^{* *}$ & 0,533 & Berhubungan \\
12 & Peran POPT & $0,000^{* *}$ & 0,518 & Berhubungan \\
\hline
\end{tabular}

Sumber: Data primer yang diolah (2021) 


\section{Hubungan Antara Umur Dengan Persepsi Petani}

Hasil dari uji korelasi rank spearman pada hubungan antara umur dengan persepsi didapatakan koefisien korelasi sebesar 0,007 yang berarti tingkat hubungannya berada pada kategorisangat rendah dengan nilai signifikansi sebesar 0,951 yang mana nilai tersebut lebih dari $5 \%(>0,05)$. Tidak terdapat hubungan yang signifikan antara umur dengan persepsi petani ubi jalar terhadap feromon lanas dan insektisida nabati daun mimba. Meskipun umur petani mayoritas berada pada rentang usia produktif namun persepsinya masih belum cukup baik. Sehingga berbeda dengan pernyataan Rahmawati (2016), yang menuturkan bahwa dalam umur produktif seseorang akan memiliki respon yang baik. Hal ini terjadi dikarenakan petani dalam kajian ini lebih memandang dari segi manfaat yang telah dirasakan dari inovasi tersebut tanpa memandang umur nya sendiri.

\section{Hubungan Antara Tingkat Pendidikan Dengan Persepsi Petani}

Berdasarkan hasil uji korelasi rank spearman pada hubungan antara tingkat pendidikan didapatakan koefisien korelasi sebesar 0,061 dengan nilai signifikansi sebesar 0,608 > 0,05. Dapat disimpulkan bahwa tidak ada hubungan yang signifikan antara tingkat pendidikan dengan persepsi petani terhadap feromon lanas dan insektisida nabati daun mimba. Hal tersebut bertentangan dengan pernyataan Notoatmodjo (2007) yang menjelaskan bahwa orang yang memiliki pendidikan tinggi dapat memberikan tanggapan yang lebih rasional dibandingkan dengan orang yang berpendidikan rendah. Perbedaan tersebut terjadi dikarenakan petani lebih menilai sesuatu yang sudah dilihat dan dirasakannya seperti efektifitas dari inovasi feromon lanas dan insektisida nabati ini tanpa menghiraukan rentang pendidikan terakhir yang ditempuhnya.

\section{Hubungan Antara Luas Lahan Dengan Persepsi Petani}

Hasil uji korelasi rank spearman pada hubungan antara luas lahan dengan persepsi petani terhadap feromon lanas dan insektisida nabati daun mimba didapatakan nilai signifikansi sebesar 0,024 . Sehingga luas lahan memiliki keterhubungan dengan persepsi petani. Koefisien korelasi sebesar 0,266 yang berarti tingkat hubungannya berada pada kategori rendah. Luas lahan memiliki keterhubungan dengan persepsi petani dikarenakan petani yang memiliki lahan lebih luas akan lebih berani dan optimis untuk mencoba inovasi baru yang dirasa menguntungkan bagi mereka dikarenakan petani tidak merasa tanggung dalam mengaplikasikan inovasi tersebutsehingga memiliki persepsi yang lebih baik. Sesuai dengan penelitian Armia (2020) yang menyebutkan semakin luas lahan yang dimiliki petani semakin baik pula persepsi petani, maka hubungan antara luas lahan dengan persepsi petani sama rata.

\section{Hubungan Antara Pendapatan Dengan Persepsi Petani}

Hasil uji korelasi rank spearman pada hubungan antara pendapatan dengan persepsi petani terhadap feromon lanas dan insektisida nabati daun mimba didapatakan nilai signifikansi sebesar 0,044 yangmana nilai tersebut berada pada $<0,05$. Sehingga luas lahan memiliki keterhubungan dengan persepsi petani. Koefisien korelasi sebesar 0,238 yang berarti tingkat hubungannya berada pada kategori rendah. Sesuai dengan hasil penelitian Beding (2017) yang menyebutkan bahwa pendapatan petani berhubungan nyata dengan persepsi petani dalam penelitiannya terhadap pengelolaan usahatani padi secara terpadu. Hal ini dikarenakan pendapatan petani merupakan kemampuan petani dari segi finansial dalam menjalankan usahatani, sehingga apabila semakin kecil 
pendapatan petani maka persepsi petani akan semakin kurang baik dikarenakan petani merasa tidak membutuhkannya dan lebih memilih untuk memenuhi kebutuhan utama lainnya.

\section{Hubungan Antara Akses Informasi Dengan Persepsi Petani}

Hasil uji korelasi rank spearman pada hubungan antara akses informasi dengan persepsi petani terhadap feromon lanas dan insektisida nabati daun mimba didapatakan nilai signifikansi sebesar 0,002 sehingga akses informasi memiliki hubungan dengan persepsi petani. Koefisien korelasi sebesar 0,362 yang berarti tingkat hubungannya berada pada kategori rendah. Hal ini sejalan dengan penelitian (Aprilia et al. 2020) bahwa akses informasi dapat berperan secara nyata terhadap persepsi petani dalam mendukung petani untuk menjalankan usaha tani dengan baik. Dalam hal ini petani ubi jalar di Kecamatan Maja yang lebih banyak memiliki akses informasi baik itu secara tatap muka atau diskusi dengan sesama petani atau petugas dari dinas pertanian dan balai penyuluhan pertanian setempat, ataupun melalui media elektronik smartphone dari platform youtube dan juga grup komunitas sesama petani di facebook akan memiliki persepsi yang lebih baik dibandingkan yang jarang atau kesulitan akses informasi.

\section{Hubungan Antara Ketersediaan Bahan Pestisida Dengan Persepsi Petani}

Hasil uji korelasi rank spearman pada hubungan antara ketersediaan bahan pestisida dengan persepsi petani terhadap feromon lanas dan insektisida nabati daun mimba didapatakan nilai signifikansi pada level 1\%. Ketersediaan bahan pestisida memiliki hubungan dengan persepsi petani. Koefisien korelasi sebesar 0,491 yang berarti tingkat hubungannya berada pada kategori rendah. Sama seperti indikator ketersediaan bahan pestisida, ketersediaan bahan penunjangpun berhubungan dengan persepsi petani. Sesuai dengan penelitian dari Irwansyah (2019), bahwasanya terdapat hubungan positif antara ketersediaan sarana produksi dengan persepsi petani. Sarana penunjang yang dimaksud dalam kajian ini berupa alat-alat dan bahan yang mendukung dalam pemasangan perangkap feromon serta dalam pembuata insektisida nabati. Dari hasil analisis diketahui bahwa ketersediaan bahan dan ketersediaan sarana penunjang belum memadai. Hal ini karena masih terbatasnya ketersediaan bahan utama pestisida mengakibatkan persepsi petani di Kecamatan Maja ini masih rendah sehingga diperlukan kemudahan bagi petani mendapatkan ketersediaan feromon dan daun mimba untuk dapat lebih memanfaatkan ketersediaan bahan penunjang yang sudah tersedia tersebut.

\section{Hubungan Antara Ketersediaan Sarana Penunjang Dengan Persepsi Petani}

Hasil uji korelasi rank spearman pada hubungan antara ketersediaan sarana dengan persepsi petani terhadap feromon lanas dan insektisida nabati daun mimba didapatakan nilai signifikansi pada level $1 \%$. Ketersediaan sarana memiliki hubungan dengan persepsi petani. Koefisien korelasi sebesar 0,441 yang berarti tingkat hubungannya berada pada kategori rendah. Sesuai dengan penelitian dari Irwansyah (2019), terdapat hubungan positif antara ketersediaan sarana produksi dengan persepsi petani. Sarana yang dimaksud dalam kajian ini berupa bahan utama pestisida berupa feromon dan daun mimba. Dari hasil analisis diketahui bahwa rendahnya ketersediaan bahan pestisida mengakibatkan rendahnya persepsi petani sehingga diperlukan kemudahan bagi petani dalam mendapatkan ketersediaan feromon dan daun mimba untuk mendorong petani dalam melaksanakan inovasi tersebut. 


\section{Hubungan Antara Intensitas Penggunaan Bahan Kimia Dengan Persepsi Petani}

Hasil uji korelasi rank spearman pada hubungan antara efektifitas bahan kimia dengan persepsi petani terhadap feromon lanas dan insektisida nabati daun mimba didapatakan nilai nilai signifikansi pada level $1 \%$. Intensitas penggunaan bahan kimia memiliki keterhubungan dengan persepsi petani. Koefisien korelasi sebesar 0,514 yang berarti tingkat hubungannya berada pada kategori sedang. Berdasarkan hasil penelitian Affandi (2014) bahwasanya intensitas dan efektifitas pestisida kimia mempunyai hubungan dengan persepsi. Petani yang sudah mengetahui dampak negatif akibat penggunaan pestisida kimia yang berlebihan akan memiliki persepsi yang lebih baik ketika dikenalkan dengan inovasi pengendalian yang ramah lingkungan berbeda halnya dengan petani yang masih memiliki ketergantungan yang berlebih terhadap pestisida kimia yang merasa lebih pesimis terhadap penggunaan inovasi lain.

\section{Hubungan Antara Kapasitas Pengendalian Hama Dengan Persepsi Petani}

Hasil uji korelasi rank spearman pada hubungan antara kapasitas pengendalian hama dengan persepsi petani terhadap feromon lanas dan insektisida nabati daun mimba didapatakan nilai signifikansi sebesar 0,002. Sehingga kapasitas pengendalian hama memiliki keterhubungan dengan persepsi petani. Koefisien korelasi sebesar 0,366 yang berarti tingkat hubungannya berada pada kategori rendah. Sesuai dengan penelitian Tandi (2013) bahwasanya persepsi petani dalam pengendalian hama dan penyakit pada suatu tanaman masih didasarkan pada kapasitas terhadap penggunaan teknologi sebelumnya yang sudah dilaksanakan dari kapasitas seperti keterampilan dan pengalaman petani itu sendiri dalam mengendalikan hama dan penyakit pada tanaman yang dibudidayakan.

\section{Hubungan Antara Peran Kelompok tani Dengan Persepsi Petani}

Hasil uji korelasi rank spearman pada hubungan antara peran kelompok tani dengan persepsi petani terhadap feromon lanas dan insektisida nabati daun mimba didapatakan nilai signifikansi sebesar 0,001 yangmana nilai tersebut berada pada < 0,05 oleh karena itu $\mathrm{H}_{0}$ ditolak dan $\mathrm{H}_{1}$ diterima. Sehingga peran kelompok tani memiliki keterhubungan dengan persepsi petani. Koefisien korelasi sebesar 0,381 yang berarti tingkat hubungannya berada pada kategori rendah. Hal tersebut sesuai dengan kajian dari Ritonga (2019) yang menyatakan bahwa peran kelompok secara parsial berhubungan terhadap persepsi petani. Didukung pernyataan dari Aprilia (2020) bahwasanya semakin tinggi peran kelompok tani maka persepsi petani akan semakin baik dan penyebar luasan teknologi dalam kelompok akan menjadi mudah dan cepat dilaksanakan. Begitu pula sebaliknya apabila peran kelompok tani tidak begitu aktif maka penyebaran informasi teknologi seperti inovasi pengendalian hama lanas ini akan sulit.

\section{Hubungan Antara Peran Penyuluh Dengan Persepsi Petani}

Hasil uji korelasi rank spearman pada hubungan antara peran penyuluh dengan persepsi petani terhadap feromon lanas dan insektisida nabati daun mimba didapatakan nilai nilai signifikansi pada level $1 \%$. Nilai tersebut berada pada $<0,05$ shingga $\mathrm{H}_{0}$ ditolak dan $\mathrm{H}_{1}$ diterima. Peran penyuluh memiliki keterhubungan dengan persepsi petani. Koefisien korelasi sebesar 0,533 yang berarti tingkat hubungannya berada pada kategori sedang. Dalam hal ini semakin sering petani melakukan interaksi dengan penyuluh pertanian maka akan semakin terbuka wawasannya dalam 
melaksanakan usahatani yang baik sehingga menimbulkan persepsi yang positif. Hal ini sejalan dengan penelitian Padillah et al. (2018) bahwa semakin tinggi intensitas interaksi petani dengan penyuluh maka tingkat persepsi petani akan semakin meningkat. Hal ini dikarenakan interaksi petani dengan penyuluh merupakan suatu hubungan yang menjalin komunikasi untuk saling bertukar informasi sehingga petani sangat membutuhkan peran penyuluh pertanian dalam mendukung kegiatan usaha taninya.

\section{Hubungan antara Peran POPT dengan Persepsi Petani}

Hasil uji korelasi rank spearman pada hubungan antara Peran POPT dengan persepsi petani terhadap feromon lanas dan insektisida nabati daun mimba didapatakan nilai nilai signifikansi pada level $1 \%$ yang mana nilai tersebut berada pada $<0,05$ sehingga $\mathrm{H}_{0}$ ditolak dan $\mathrm{H}_{1}$ diterima. Peran POPT memiliki hubungan dengan persepsi petani dengan koefisien korelasi sebesar 0,518 yang berarti tingkat hubungannya berada pada kategori sedang. Semakin banyak petani berinteraksi dengan POPT maka dapat memberikan informasi yang lebih luas berkaitan pengendalian hama sehingga persepsi yang baik akan muncul ketika petani dikenalkan dengan inovasi yang dirasa menguntungkannya. Sesuai dengan penelitian Aprianto et al. (2020) yang menyebutkan intensitas sosial petani dengan POPT dapat memberikan kontribusi pembentukan persepsi petani terhadap pengendalian hama terpadu.

\section{Model dan Strategi Peningkatan Persepsi Petani}

Penyerapan teknologi daripada inovasi seperti penggunaan feromon dan insektisida nabati daun mimba membutuhkan suatu proses pemahaman berupa persepsi oleh para petani Didukung pernyataan Aditiawati et al. (2014) yang menyebutkan bahwa suatu inovasi akan lebih diserap dan diadopsi apabila petani itu sendiri memiliki pandangan atau persepsi yang baik terhadap inovasi tersebut. Sejalan dengan pernyataan Kusumawati (2012) bahwa persepsi yang baik atau positif adalah dasar belajar yang baik. Begitu juga sebaliknya, seseorang yang memiliki persepsi yang tidak baik atau negatif, maka ia akan mengalami kesulitan dalam belajar. Persepsi yang baik merupakan awal daripada terbentuknya perilaku petani yang terbuka untuk dapat meningkatkan usahatani nya.

Berdasarkan hasil penelitian dapat diketahui bahwa persepsi petani ubi jalar terhadap penggunaan feromon serta insektisida nabati daun mimba termasuk kedalam kategori kurang baik. sehingga diperlukan suatu strategi dalam upaya untuk meningkatkan persepsi petani. Strategi tersebut dilakukan dengan meningkatkan dan mengoptimalkan faktor- faktor yang memiliki hubungan secara nyata dengan persepsi petani.

Dari hasil analisis rank spearman diketahui bahwasanya faktor-faktor yang memiliki hubungan secara nyata dengan persepsi petani pada kajian ini yakni intensitas penggunaan bahan kimia, peran penyuluh pertanian serta peran POPT.

Berikut merupakan strategi yang dapat dilaksanakan untuk meningkatkan tingkat persepsi petani terhadap penggunaan feromon dan insektisida nabati daun mimba adalah:

1. dalam upaya penurunan penggunaan ketergantungan terhadap penggunaan pestisida kimia kegiatan perlindungan tanaman melalui pestisida nabati perlu dimasyarakatkan untuk melindungi lingkungan hidup dari bahan kimia pestisida dan membentuk persepsi petani yang lebih baik terhadap pestisida nabati 
seperti feromon dan insektisida nabati. Salah satu upaya pemasyarakatan tersebut adalah dengan melaksanakan penyebarluasan informasi jenis-jenis tumbuhan yang berpotensi sebagai pestisida nabati, yang dapat dimanfaatkan dalam pengendalian hama dan penyakit.

2. peningkatan kemampuan sumber daya manusia baik dari petani, penyuluh, POPT yang bertugas di lapangan. Diantaranya dengan melaksanakan pelatihan baik dalam bentuk penyuluhan, SL-PHT dan lainnya. Dengan pelatihan, pengetahuan tentang pestisida nabati dapat lebih meningkat serta rekomendasi atau dorongan dalam pengambilan persepsi ditumbuhkan. Untuk petani materi pelatihan lebih ditekankan pada hal-hal yang bersifat praktis yaitu cara mengaplikasikan dan menyebarluaskan Sehingga diharapkan petani yang telah dilatih dapat menjadi agen penyebarluasan pemasyarakatän kepada anggota kelompok taninya sehingga upaya dapat lebih efektif dan efisien.

3. diharapkan petani yang telah dilatih dapat menjadi agen penyebarluasan pemasyarakatan kepada anggota kelompok taninnya. Sehingga upaya pemasyarkatan dapat lebih efektif dan efisien.

4. Melaksanakan pertemuan atau lokakarya. Hal ini merupakan salah satu sarana yang efektif, karena petani pengguna dapat berbagi pengalaman ke petani yang belum pernah mencobanya. Terlebih peranan media massa dalam era komunikasi pada saat ini mempunyai peranan penting. Karena hampir setiap keluarga petani mempunyai handphone, televisi dan mungkin berlangganan surat kabar.

\section{RANCANGAN DAN PELAKSANAAN PENYULUHAN}

\section{Rancangan Kegiatan Penyuluhan}

Faktor yang memiliki tingkat hubungan paling tinggi pada analisis rank spearman yang telah dilakukan yakni pada peran penyuluh pertanian. Pada dasarnya peran daripada penyuluh pertanian adalah untuk mengubah perilaku baik itu dari segi pengetahuan, sikap bahkan keterampilan dari petani. Oleh karena itu, salah satu cara yang dapat dilakukan untuk dapat meningkatkan persepsi petani yakni dengan melalui kegiatan penyuluhan. Kegiatan penyuluhan ini dalam kajian ini merupakan suatu bentuk dalam upaya tindak lanjut dari strategi yang telah dirumuskan untuk dapat membentuk persepsi petani yang lebih baik. Berkaitan dengan strategi tersebut, selanjutnya disusun suatu rancangan penyuluhan pertanian adalah sebagai berikut:

1. materi penyuluhan

Materi penyuluhan yang disampaikan kepada petani ubi jalar di Kecamatan Maja dipilin berdasarkan hasil analisis deskriptif. Materi utama diambil berdasarkan skor terendah pada analisis deskriptif. Berdasarkan hasil analisis yang telah dilakukan diketahui bahwa yang akan dijadikan materi utama berkaitan indikator kemudahan dicoba dilakukan dengan pelaksanaaan penyuluhan dengan demonstrasi cara pembuatan dan pemasangan perangkap feromon lanas.

2. media penyuluhan

Media penyuluhan digunakan dalam memperjelas materi dan pesan yang hendak disampaikan kepada petani sehingga mampu menimbulkan semangat belajar dan meunculkan interaksi langsung 
dengan petani. Media yang digunakan dalam kajian ini berupa kombinasi dari penggunaan berbagai media seperti media sesungguhnya berupa feromon dan botol, media tercetak seperti leaflet, media audio visual dengan menggunakan video dan powerpoint.

3. metode penyuluhan

Metode yang digunakan
dalam kajian ini ini merupakan
kombinasi dari beberapa metode
agar dapat memaksimalkan
penyampaian materi sehingga lebih
dipahami dan diterapkan oleh petani
sasaran di Kecamatan Maja. Metode
penyuluhan berupa kegiatan
demonstrasi cara, ceramah, diskusi,
dan demonstrasi plot dalam skala
kecil atau disebut petak
percontohan.

4. frekuensi penyuluhan

Frekuensi dari pelaksanaan penyuluhan dilaksanakan satu kali pada setiap kelompok tani, sehingga total frekuensi penyuluhan enam kali pertemuan Mei sampai Juni 2021.

\section{Pelaksanaan Penyuluhan}

Pelaksanaan kegiatan penyuluhan dilaksanakan sebagai bentuk upaya tindak lanjut daripada kegiatan kajian yang telah dilaksanakan dalam rangka memperkuat materi yang masih lemah atau belum dikuasai oleh para petani/kelompok tani sasaran kajian. Berdasarkan dari strategi dari hasil analisis yang telah dicanangkan maka pelaksanaan kegiatan penyuluhan dalam upaya untuk meningkatkan persepsi petani ubi jalar menjadi positif dilakukan sebanyak enam kali pertemuan pada setiap kelompok tani responden yakni Banjaran I, Cibuni, Cigolat, Nanggerang Selapraja I dan Selapraja II.

Pemilihan materi penyuluhan berdasarkan analisis deskriptif dengan mengurutkan peringkat terendah pada skor indikator persepsi petani sehingga dapat diketahui ranking dari parameter yang terendah sampai dengan yang tertinggi. Dari pengurutan nilai hasil analisis kategori rendah maka parameter tersebut akan dijadikan sebagai prioritas dalam penentuan materi penyuluhan. Perolehan skor persepsi petani pada Tabel 4 .

Tabel 4 Perankingan Indikator Persepsi Petani

\begin{tabular}{rlcccc}
\hline No. & \multicolumn{1}{c}{$\begin{array}{c}\text { Persepsi } \\
\text { Petani }\end{array}$} & Skor & $\begin{array}{c}\text { Parameter } \\
\text { Terendah }\end{array}$ & $\begin{array}{c}\text { Skor } \\
\text { Terendah }\end{array}$ & Ranking \\
\hline 1. & $\begin{array}{l}\text { Keunggulan } \\
\text { Relative }\end{array}$ & 112 & $\mathrm{Y}_{1.1 .1}$ & 2,477 & 5 \\
2. & $\begin{array}{l}\text { Tingkat } \\
\text { Kesesuaian }\end{array}$ & 108,5 & $\mathrm{Y}_{1.2 .2}$ & 2 & 3 \\
3. & $\begin{array}{l}\text { Tingkat } \\
\text { Kerumitan } \\
\text { Kemudahan }\end{array}$ & 70,5 & $\mathrm{Y}_{1.3 .3}$ & 1,409 & 2 \\
5. & 65 & $\mathrm{Y}_{1.4 .2}$ & 1,364 & 1 \\
\hline
\end{tabular}

Sumber: Data primer yang diolah (2021)

Upaya agar penyuluhan efektif dan terarah, maka disusun lembar persiapan menyuluh (LPM), sinopsis materi, media alat peraga, media leaflet, media tayangan slide power point dan daftar hadir pertemuan. Materi penyuluhan tiap indkator meliputi keunggulan, kesesuaian feromon lanas terhadap lingkungan, kemudahan pemasangan perangkap, pemasangan perangkap, dan perkiraan hama lanas yang terperangkap secara rinci ditunjukkan pada Tabel 5. 
Tabel 5 Materi Penyuluhan Per Indikator

\begin{tabular}{|c|c|c|c|c|}
\hline No. & Materi & Tujuan & Media & Metode \\
\hline 1. & $\begin{array}{l}\text { Keunggulan } \\
\text { feromon lanas }\end{array}$ & $\begin{array}{l}\text { Memahami Keunggulan } \\
\text { dari Penggunaan } \\
\text { Perangkap Feromon }\end{array}$ & $\begin{array}{l}\text { PPT dan } \\
\text { Leaflet }\end{array}$ & $\begin{array}{l}\text { Ceramah, Diskusi } \\
\text { dan Demonstrasi } \\
\text { Cara }\end{array}$ \\
\hline 2. & $\begin{array}{l}\text { Kesesuaian } \\
\text { Feromon Lanas } \\
\text { terhadap } \\
\text { Lingkungan }\end{array}$ & $\begin{array}{l}\text { Memahami manfaat } \\
\text { Feromon terhadap } \\
\text { lingkungsn }\end{array}$ & $\begin{array}{l}\text { PPT dan } \\
\text { Leaflet }\end{array}$ & $\begin{array}{l}\text { Ceramah, Diskusi } \\
\text { dan Demonstrasi } \\
\text { Cara }\end{array}$ \\
\hline 3. & $\begin{array}{l}\text { Kemudahan } \\
\text { pemasangan } \\
\text { perangkap }\end{array}$ & $\begin{array}{l}\text { Mengetahui cara } \\
\text { pemasangan dan } \\
\text { penggunaan Feromon }\end{array}$ & $\begin{array}{l}\text { PPT, } \\
\text { Leaflet } \\
\text { dan Alat Peraga }\end{array}$ & $\begin{array}{l}\text { Ceramah, Diskusi } \\
\text { dan Demonstrasi } \\
\text { Cara }\end{array}$ \\
\hline 4. & $\begin{array}{l}\text { Pembuatan dan } \\
\text { Pemasangan } \\
\text { Perangkap } \\
\text { Feromon lanas }\end{array}$ & $\begin{array}{l}\text { Mengetahui cara } \\
\text { pembuatan insektisida } \\
\text { nabati }\end{array}$ & $\begin{array}{l}\text { PPT, } \\
\text { Leaflet } \\
\text { dan Alat Peraga }\end{array}$ & $\begin{array}{l}\text { Ceramah, Diskusi } \\
\text { dan Demonstrasi } \\
\text { Cara }\end{array}$ \\
\hline 5. & $\begin{array}{l}\text { Perkiraan Hama } \\
\text { Lanas yang } \\
\text { terperangkap }\end{array}$ & $\begin{array}{l}\text { Memperkirakan hama } \\
\text { lanas yang terjebak } \\
\text { dalam perangkap } \\
\text { Feromon }\end{array}$ & $\begin{array}{l}\text { PPT, } \\
\text { Leaflet } \\
\text { dan Alat Peraga }\end{array}$ & $\begin{array}{l}\text { Ceramah, Diskusi } \\
\text { dan Demonstrasi } \\
\text { Cara }\end{array}$ \\
\hline
\end{tabular}

Sumber: Data primer yang diolah (2021)

Berdasarkan parameter terendah yang akan dijadikan materi utama berkaitan indikator kemudahan dicoba dilakukan dengan pelaksanaaan penyuluhan dengan demonstrasi cara pembuatan dan pemasangan perangkap feromon lanas. Kegiatan penyuluhan ini dilakukan pada enam kelompok tani yang menjadi responden dengan frekuensi satu kali penyuluhan pada masing-masing kelompok tani.

Berdasarkan Tabel 5 dapat diketahui bahwasanya metode yang digunakan dalam pelaksanaan penyuluhan menggunakan ceramah, diskusi dan pelaksanaan demonstrasi cara. Metode tersebut digunakan karena dalam pengkajian ini indikator persepsi yang hendak ditingkatkan agar lebih baik dari segi kemudahan dicoba, sehingga digunakan metode yang mampu merangsang semua panca indra serta dapat dipraktekan langsung oleh petani.

Pelaksanaan penyuluhan didasarkan pada acuan yang tertuang pada LPM serta didukung oleh sinopsis sebagai ringkasan materi yang akan disampaikan. Metode awal yang dilakukan dalam kegiatan penyuluhan pada kajian ini adalah ceramah sebagai pengantar perkenalan dan juga pengantar pengetahuan dari materi yang hendak disampaikan kepada petani, dengan menjelaskan secara rinci poin-poin penting yang terdapat pada media yang disampaikan sehingga petani dapat memahami dengan baik. Metode diskusi juga dilakukan untuk dapat melihat respon dan perhatian dari petani serta untuk melihat tingkat pengetahuan petani tentang materi yang disampaikan dan melakukan tukar pendapat dan pengalaman serta mengumpulkan saransaran untuk memecahkan permasalahan.

Dari hasil pelaksanaan penyuluhan berkaitan perangkap feromon lanas ini mendapatkan respon positif di setiap kelompok tani. Hal ini dikarenakan metode yang digunakan seperti alat peraga dan penyampaian hasil dari pengamatan pada petak percontohan yang disampaikan kepada petani ubi jalar. Setelah dilaksanakannya penyuluhan, petani mampu mengetahui pengertian, manfaat yang dapat serta menerapakan cara pemasangan perangkap feromon lanas 
sehingga persepsi petani ubi jalar di kecamatan Maja pada feromon lanas dan insektisida nabati daun mimba meningkat.

\section{Hasil Penggunaan Feromon dan Insektisida Nabati Daun Mimba}

Petak percontohan dilakukan untuk mendemonstrasikan efektifitas penggunaan teknologi yang dihasilkan dengan cara menerapkannya pada lahan milik petani. Petak percontohan yang telah dilaksanakan adalah dengan membudidayakan ubi jalar dengan memasang perangkap feromon lanas pada hari ke-7 setelah tanam serta penyemprotan insektisida nabati daun mimba pada setiap 1 bulan sekali yang dimulai pada minggu ke-2 atau 14 HST. Pada pengamatan yang dilakukan adalah dengan cara mengamati jumlah hama lanas yang terperangkap pada perangkap Feromon. Tujuan dari pengamatan ini untuk menunjukkan bahwa perangkap Feromon mampu mengendalikan serangan hama lanas pada tanaman ubi jalar. Sehingga diharapkan persepsi petani terhadap pengendalian hama lanas melalui penggunaan Feromon mengalami Hasil pengamatan pemasangan perangkap feromon pada Tabel 6 .

Tabel 6 Hasil Pengamatan Pemasangan Perangkap Feromon

\begin{tabular}{ccccc}
\hline No. & Waktu & Perangkap A & Perangkap B & Perangkap C \\
\hline 1. & Pekan ke-1 & 29 & 22 & 10 \\
2. & Pekan ke-2 & 28 & 11 & 13 \\
3. & Pekan ke-3 & 34 & 18 & 10 \\
4. & Pekan ke-4 & 41 & 20 & 10 \\
5. & Pekan ke-5 & 33 & 20 & 9 \\
6. & Pekan ke-6 & 30 & 17 & 15 \\
7. & Pekan ke-7 & 36 & 17 & 19 \\
8. & Pekan ke-8 & 44 & 24 & 22 \\
9. & Pekan ke-9 & 37 & 21 & 25 \\
10. & Pekan ke-10 & 35 & 16 & 26 \\
\hline & Rata-rata & $\mathbf{3 4 , 7}$ & $\mathbf{1 8 , 6}$ & $\mathbf{1 5 , 9}$
\end{tabular}

Sumber: Data primer yang diolah (2021)

Pada setiap perangkapnya diberikan perlakuan yang berbeda yakni perbedaan ketinggian dari permukaan tanah dalam pemasangan perangkap feromon lanas. Untuk perangkap A dengan ketinggian sekitar $5-10 \mathrm{~cm}$, perangkap $B$ dengan ketinggian 10-15 cm dan perangkap $C$ dipasang di ketinggian 15-20 $\mathrm{cm}$ di atas permukaan tanah. Hasil pengamatan yang telah dilakukan pada setiap pekannya menunjukkan bahwa perangkap dengan ketinggian berkisar 5-10 $\mathrm{cm}$ lebih efektif dibandingkan perlakuan lainnya dengan rata-rata 34,7 ekor. Hal ini dikarenakan pada ketinggian tersebut hama lanas yang berada pada tanah dapat lebih menjangkau perangkap sehingga lebih banyak yang mampu terjebak pada perangkap A. Jumlah tertinggi hama lanas yang terjebak dalam perangkap terjadi pada pekan ke-8 yangmana pada pekan tersebut umbi ubi jalar sudah masuk ke dalam fase pengisian umbi. Penggunaan perangkap feromon ini tentunya dapat lebih dirasakan manfaatnya secara langsung jika dibandingkan dengan tanaman umbi jalar 
yang tidak diberikan perlakuan, atau dilakukan penyemprotan pestisida yang tidak dapat diamati jumlah hama yang terkena dampaknya.

\section{SIMPULAN}

1. Persepsi petani ubi jalar di Kecamatan Maja masih berada pada kategori kurang baik dengan nilai 49,9\%. Hal ini dikarenakan minimnya informasi yang didapatkan serta ketersediaannya yang masih jarang terdapat di kios tani terdekat serta kcenderungan petani dalam menggunakan pestisida kimia.

2. Faktor-faktor yang memiliki hubungan dengan persepsi petani pada kajian ini yakni luas lahan, pendapatan, akses informasi, ketersediaan bahan pestisida, ketersediaan bahan penunjang, intensitas penggunaan pestisida, kapasitas dalam PHT, peran kelompok tani, peran penyuluh pertanian serta peran POPT.

3. Strategi yang dilakukan untuk meningkatkan persepsi petani yakni dengan pelaksanaan penyuluhan dengan materi utama pembuatan dan pemasangan perangkap feromon lanas, dan 4) penggunaan perangkap feromon dapat lebih dirasakan manfaatnya secara langsung jika dibandingkan dengan penyemprotan pestisida yang tidak dapat diamati jumlah hama.

\section{SARAN}

Berdasarkan hasil penelitian yang telah dilakukan maka dapat disarankan untuk mengajak petani untuk membentuk kios usaha tani yang dikelola secara kelompok agar petani tidak sulit lagi untuk memperoleh saprotan, memberikan penyuluhan dan pelatihan baik kepada petani, penyuluh maupun petugas POPT terkait dengan pembuatan perangkap feromon lanas ini secara intensif serta memberikan pengawalan saat program ini dilaksanakan.

\section{DAFTAR PUSTAKA}

[BPP] Balai Penyuluhan Pertanian. 2021. Programa Penyuluhan Pertanian BPP Kecamatan Maja Tahun 2021. Dinas Ketahanan Pangan Pertanian dan Perikanan Kabupaten Majalengka

[BPS] Badan Pusat Statistik. 2020. Kecamatan Maja dalam Angka 2020: Badan Pusat Statistik Kabupaten Majalengka.

Aditiawati, P., Rosmiati, M. and Sumardi, D., 2014. Persepsi Petani Terhadap Inovasi Teknologi Pestisida Nabati Limbah Tembakau (Suatu Kasus Pada Petani Tembakau di Kabupaten Sumedang). Sosiohumaniora, 16(2), pp.184192.

Affandi A, Sinaga A. 2014. Hubungan Pengetahuan dan Persepsi Harga dengan Penggunaan Pestisida dalam Usahatani. Jurnal Agribisnis Indonesia, 2(2), 93-106.

Aprianto KK, Dayat D, Widyastuti N. 2020. Persepsi Petani Terhadap Pengendalian Hama Terpadu (PHT) pada Usaha Tani Cabai Rawit (Capsicum Frutescens $L$ ) di Desa Padasuka Kecamatan Petir Kabupaten Serang. Jurnal Inovasi Penelitian, 1(3), 371-380.

Aprilia K, Kusnadi D, Harniati H. 2020. Persepsi Petani Padi terhadap Sistem Tanam Jajar Legowo di Desa Sukaharja Kecamatan Ciomas Kabupaten Bogor. Jurnal Inovasi Penelitian, 1(3), 435-444.

Armia, N.U., Gultom, D.T. and Effendi, I., 2020. Persepsi Petani Anggota P3A terhadap Pengelolaan Irigasi Usahatani Padi Sawah di Kelurahan Margodadi Kecamatan Metro Selatan Kota Metro. Jurnal IImu IImu Agribisnis: Journal of Agribusiness Science, 8(2), pp.359-365.

AW Van den Ban, dan Hawkins HS. 1999. 
Penyuluhan Pertanian. Kanisius Yogyakarta.

Beding, Petrus A. 2017. Persepsi Petani terhadap Inovasi Teknologi Pengelolaan Tanaman Terpadu Padi Gogo di Kabupaten Sarmi Provinsi Papua. Agritech: Jurnal Fakultas Pertanian Universitas Muhammadiyah Purwokerto 17, no. 1 (2017): 65-72.

Capinera, J.L. 2014. Sweet Potato Weevil, Cylas formicarius (Fabricius). Instituteof Food and Agricultural Sciences. University of Florida.

Irwansyah, B. 2019. Persepsi Petani Dalam Budidaya Kopi Organik Di Kecamatan Pematang Sidamanik Kabupaten Simalungun. Jurnal Politeknik Pembangunan Pertanian: Medan.

Kusnadi N, Tinaprilla N, Susilowati, dan Purwoto. 2011. Analisis efisiensi usahatani padi di beberapa sentra produksi padi di Indonesia. JAE,29 (1):25-48

Lapinangga, N. J., \& da Lopez, Y. F. 2018. Pemanfaatan Bahan Nabati Lokal Berefek Pestisida untuk Mengendalikan Hama Cylas formicarius pada Tanaman Ubi Jalar. Agrovigor: Jurnal Agroekoteknologi, 11(1), 34-38.

Notoatmodjo S. 2007. Konsep Perilaku dan Perilaku Kesehatan. Dalam: Promosi Kesehatan dan IImu Perilaku. Rineka Cipta, Jakarta, 133-151.

Padillah, P., Purnaningsih, N. and Sadono, D., 2018. Persepsi Petani tentang Peranan Penyuluh dalam Peningkatan Produksi Padi di Kecamatan Tabir Kabupaten
Merangin Provinsi Jambi. Jurnal Penyuluhan, 14(1), pp.1-10.

Pasaribu, A. A. 2018. Analisis dan Kontrol Optimal Model Matematika Populasi Hama-Serangga dengan Perangkap Feromon (Doctoral dissertation, Universitas Airlangga).

Rahmawati A, Gitosaputro S, Viantimala B. 2016. Respon Petani Terhadap Pelayanan Kupra Sebagai Pengganti Kur di Bri Putra Rumbia Kabupaten Lampung Tengah. In SNPPT (Vol. 1, No. 01).

Ritonga, M. F. A. 2019. Persepsi Petani dalam Penerapan Sistem Pertanian Organik pada Budidaya Kakao (Theobroma cacao L.) di Kecamatan Gebang Kabupaten Langkat. Jurnal Polbangtan Medan

Rogers, E.M. 2005. Diffusion of Innovasion. The free Press of MacMillan Publ. Co. Canada

Sugiyono. 2019. Metode Penelitian Kuantitatif, Kualitatif, dan $R \& D$. Bandung: Alfabeta, CV

Supriyatin S. 2008. Hama Boleng pada Ubijalar dan Cara Pengendaliannya. Buletin Palawija, (2), 22-29.

Tandi I. 2013. Perilaku Petani dalam Pengendalian Hama dan Penyakit pada Tanaman Kentang di Desa Kanreapia Kecamatan Tombolopao Kabupaten Gowa. Jurnal Agrisistem: Seri Sosek dan Penyuluhan, 9(2), 90-101. 